九州大学学術情報リポジトリ

Kyushu University Institutional Repository

Comparision of Nutritional Composition and Histological Changes of the Soybean Seeds Cultivated by Conventional and Organic Farming Systems after Long-Term Storage : Preliminary Study

Nakamura, Yoshinori

Faculty of Agriculture, Ehime University

Fujita, Masao

International Nature Farming Research Center, Agricultural Experiment Station

Nakamura, Yoshio

Faculty of Agriculture, Ehime University

Goto, Takafumi

Graduate School Kuju Agricultural Research Center, Faculty of Agriculture, Kyushu University

ht tps://doi.org/10.5109/9272

出版情報: 九州大学大学院農学研究院紀要. 52 (1)，pp.1-10，2007-02-28. Faculty of Agriculture， Kyushu University

バージョン :

権利関係 : 


\title{
Comparison of Nutritional Composition and Histological Changes of the Soybean Seeds Cultivated by Conventional and Organic Farming Systems after Long-Term Storage - Preliminary Study -
}

\author{
Yoshi-Nori NAKAMURA ${ }^{1 *}$, Masao FUJITA ${ }^{2}$, Yoshio NAKAMURA ${ }^{3}$ \\ and Takafumi GOTOH ${ }^{1}$
}

\author{
Graduate School Kuju Agricultural Research Center, Faculty of Agriculture, \\ Kyushu University, Kuju-cho, Oita, 878-0201, Japan \\ (Received October 10, 2006 and accepted December 1, 2006)
}

\begin{abstract}
We investigated the effect of hermetic long-term (9-year) storage at room temperature on the chemical compositions and histological structure of soybean seeds that had been cultivated by two farming systems [conventional farming (CF) or organic (natural) farming (OF)]. Soybean seeds had been harvested from plants cultivated in the field under CF practices, or in a neighboring field where OF practices had been used for over 3 years. Protein content, calcium (Ca), potassium $(\mathrm{K})$ and phosphorus $(\mathrm{P})$ content of OF soybean seeds were higher than CF seeds just after harvesting. However, after long-term storage, protein content of OF soybean seeds was significantly higher than CF seeds. In addition, there were many minerals with a higher content (in particular, K) of OF soybean seeds. The breaking strength and $\mathrm{pH}$ of $\mathrm{OF}$ soybean seeds were higher than CF ones. Optical microscopic examination revealed collapsed tissue and gaps in the internal and external parts of CF soybean seeds. Transmission electron microscopic photographs of CF soybean seeds confirmed the presence of collapsed cell walls and protein bodies. These results indicate that the type of farming system (inorganic or organic fertilizers) used results in differences in chemical compositions and histological structure of product during storage. In addition, our results indicated that high Ca content of OF soybean seeds strengthened cell wall structure, and prevented the loss of contents during storage.
\end{abstract}

KEYWORDS: histology, soybean seed, conventional farming, organic farming, storage

\section{INTRODUCTION}

Various methods, such as cool storage or $\mathrm{CO}_{2}$ gas storage, are used to keep farm products such as grains and seeds (Calderwood et al., 1984; Zhou et al., 2002). However, the quality of the products inevitably deteriorates during storage (Hoshi et al., 1982; Sripichitt et al., 1989; Yamamoto and Shirakawa, 1999; Matsue et al., 2003; Hou and Chang, 2004a, b). A number of physiological and physicochemical changes take place and are usually termed ageing (Narayan et al., 1988a, b; Zhou et al., 2002). These changes affect colour, flavour, texture and the occurrence of mold (Wilkins and Scholl, 1989; Zhou et al., 2002). Until now, there have been few reports (Benge et al., 2000; Asami et al., 2003) about changes in quality (especially chemical composition) of organically grown and conventional products under storage; furthermore, reports of comparative tests have shown that quality after storage is better in organic products than in conventional products (Asami et al., 2003; Lotter, 2003). This suggests that these differences may result from differences in the farming systems, in particular, the form of fertilizer (organic versus

\footnotetext{
Graduate School Kuju Agricultural Research Center, Faculty of Agriculture, Kyushu University, Kuju-cho, Oita, 878-0201, Japan

${ }^{2}$ International Nature Farming Research Center, Agricultural Experiment Station, 5632 Hata, Nagano, 390-1401, Japan

${ }^{3}$ Laboratory of Crop Science, Faculty of Agriculture, Ehime University, 3-5-7 Tarumi, Matsuyama City, Ehime, 790-8566, Japan

* Corresponding author: (E-mail: yoshinori1124@hotmail.com)
}

inorganic) used as a source of nutrition. However, there is little data with regard to the chemical composition and histological changes of products from conventional farming (CF) or organic (natural) farming (OF) systems after long-term storage. We assume that the degree of deterioration is determined, to some extent, by the histological structure of the cell walls and chemical composition (Narayan et al., 1988a,b; Zhou et al., 2002; Asami et al., 2003).

The method of natural farming on equal terms with OF was advocated in Japan by Okada (1982), who emphasized the importance of soil health and microbial biodiversity and is conceptually similar to the suggestions of France (1921). Taken together, our results and the reports by Okada (1982) and France (1921) indicate that the type of farming system affects the morphology of the products, and that the effect was mainly due to the type of fertilizer that was used, namely chemical or organic (Nakamura, 1988, 1989; Nakamura et al., 2003). However, the effect of the type of farming on the morphogenesis of products or change during cooking and storage has not been clarified. On the other hand, the OF system has attracted attention throughout the world (Reganold et al., 2001; Tilman et al., 2002; Altieri and Nicholls, 2003). However, until now the chemical and histological differences between $\mathrm{CF}$ and OF products have not been delineated (Woese et al., 1997; Brandt and Mølgaard, 2001). In Japanese agriculture, use of the OF system is presently in a minority, and the volume of the products produced is small (Neera et al., 1992, 1999).

We studied the chemical compositions and histologi- 
cal changes of soybean seeds that had been cultivated by $\mathrm{CF}$ or $\mathrm{OF}$ practices followed by harvest and long-term storage to evaluate the significance of organic substances and soil biota on the chemical compositions and cell morphology of soybean seeds.

\section{MATERIALS AND METHODS}

\section{Materials}

Seeds of soybean (Glycine max L. Merr. variety Horei) were sampled during the harvest season (in Nov.) from upland fields of CF and OF in the Tohoku National Agricultural Research Center in Fukushima city in a district in northeastern Japan.

Historically, the CF fields had been farmed conventionally (receiving chemical fertilizers and agricultural chemicals that were standard for the respective district), while the OF fields had been cultivated naturally for over 3 years without chemical fertilizers or agricultural chemicals and using no-till planting and weeding (which had been performed several times during the course of this study). The soil conditions and agricultural practices in Fukushima were reported in detail by Nakamura et al. (2003). Approximately $500 \mathrm{~g}$ of each material was used for this study.

\section{Storage conditions}

The materials were soybean seeds that had been harvested in 1995 and stored for 9 years under hermetic conditions at room temperature and shield from light.

\section{Measurement of dry matter, protein, lipid and ash contents after harvest and long-term storage}

Samples (100 g) from harvest and long-term storage (in Nov. 2004) were powdered, and the proximate composition was measured using the methods of Anonymous (1990). Moisture content was measured by heating the sample to $110^{\circ} \mathrm{C}$ for $18 \mathrm{~h}$. Crude protein content was measured by the Kjeldahl method. The coefficient of conversion from the amount of nitrogen to crude protein content was 5.71 based on the Standard Tables of Food Composition in Japan (STFCJ 2001). Crude lipid content was measured by the Soxhlet Extraction System (Sanyoh MFG Co. Ltd., Osaka, Japan). Crude ash content was measured by heating the sample to $600{ }^{\circ} \mathrm{C}$ for $24 \mathrm{~h}$.

Samples after harvest were measured for protein and lipid content only. In addition, each food product type was assayed in one (after harvest) or ten (after long-term storage) replicates.

\section{Simple qualitative analysis of mineral composi- tions after harvest and long-term storage}

To prevent trace metal contamination of the samples by laboratory equipment, all laboratory ware was soaked in $2 \mathrm{M} \mathrm{HNO}_{3}$ for $48 \mathrm{~h}$, rinsed five times with distilled water, and then five times with deionized water prior to use. Deionized water, of resistivity greater than $18 \Omega / \mathrm{cm}$ and pressure of $4 \mathrm{~kg} / \mathrm{cm}^{2}$ at $25^{\circ} \mathrm{C}$, was prepared by passing singly ultra-pure water through Ultra Pure
Water System (type: CPW-100-CCS-1) (Advantec Toyo Kaisha, Ltd., Tokyo, Japan). For measurement of toxic metals, tissue samples (3g) were digested with concentrated nitric acid (Wako Pure Chemical Industries, Ltd., Osaka, Japan). Samples were heat-treated at $120^{\circ} \mathrm{C}$ on a hot plate with hydrogen peroxide (Wako Pure Chemical Industries, Ltd., Osaka, Japan) until sample solution became transparent. By adding ultra-pure water, sample solutions were adjusted to $100 \mathrm{~mL}$ total volume.

Mineral content of each sample was analyzed for detectable minerals by an Inductively Coupled Plasma Atomic Emission Spectrometer (IRIS intrepid XDL) (Thermo Electron Co., Waltham, MA, USA). The final reported values are the mean of three replicate determinations. However, data of sodium $(\mathrm{Na})$ was not shown because a glass flask for the heat-treatment. Analysis conditions were: delay time, 0 ; sample substitution time, 60; and largest integral time, 20 (low) and 10 (high).

Samples after harvest were measured calcium (Ca), potassium $(\mathrm{K})$ and phosphorus $(\mathrm{P})$ levels only. In addition, each sample was assayed in one (after harvest) or three (after long-term storage) replicates.

\section{Measurement of the breaking strength after long-term storage}

Ten soybean seeds of each group, which had absorbed water for $24 \mathrm{~h}$ at room temperature, were divided into half. A blade plunger was used to cut the middle of seeds at a speed of $2 \mathrm{~cm} / \mathrm{min}$, and maximum force was recorded by a rheometer (RT-1002A, Fudoh, Tokyo, Japan) 20 times for each group and was regarded as the breaking strength.

\section{Measurement of pH after long-term storage}

The $\mathrm{pH}$ of soybean seeds after long-term storage was measured using by a $\mathrm{pH}$ meter ( $\mathrm{F}-53$; Horiba, Kyoto, Japan). The soybean samples (5g) were combined with distilled water $(20 \mathrm{~mL})$ in a test tube, and were allowed to absorb the water at $4{ }^{\circ} \mathrm{C}$ for $12 \mathrm{~h}$. Samples were homogenized for $1 \mathrm{~min}$ at 10,000 rpm at low temperature. The $\mathrm{pH}$ of the mixture was directly measured by the electrode of a pH meter. Each sample was assayed in three replicates.

\section{Scanning electron microscopy after long-term storage}

The soybean seeds were cut $1 \times 1 \mathrm{~mm}$ of surface of seed coats and surface of seeds which stripped off seed coat, and then mounted on aluminium holders with the surface of seed coats and surface of the seeds which stripped off seed coat. The specimens were coated with Pt-Pd by an Ion Sputtering Device (Quick Auto Coater JFC-1500, JEOL). The surface of seed coats and surface of seeds which stripped off seed coat were examined under a scanning electron microscope (S-2380N, Hitachi, Tokyo, Japan).

\section{Optical microscopy after long-term storage}

In Nov. 2004, each sample was analyzed by optical 
microscopy. Ten equal-length soybean seeds were randomly selected from storage bottles of each product group ( $\mathrm{CF}$ and $\mathrm{OF}$ ); they were fixed in $5 \%$ glutaraldehyde (in $0.1 \mathrm{M}$ phosphate buffer, $\mathrm{pH} 7.4$ ), stored at $4{ }^{\circ} \mathrm{C}$ for 2 weeks, cut in two longitudinally, and stored in the fixative at $4{ }^{\circ} \mathrm{C}$ for 1 additional week. After dehydration through a series of 50-to-100\% ethanol washes, samples were embedded in Technovit (Technovit 7100; Ohken Co., Tokyo, Japan), and $3 \mu \mathrm{m}$-thick, longitudinal sections were sliced using a microtome (Nippon Optical Works, Tokyo, Japan). Sections were stained with a $0.1 \%$ toluidine blue and analyzed under an optical microscope (BX-50; Olympus, Tokyo, Japan) (Fig. 1).

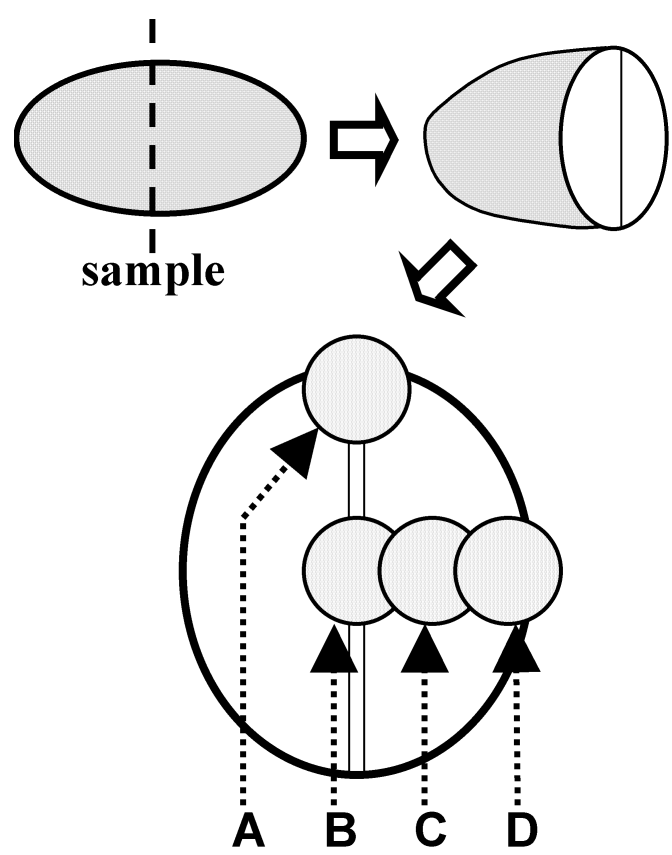

Fig. 1. Diagrams of cross-sections of soybean seeds used for optical microscopy (OM).

\section{Transmission electron microscopy after long-term storage}

Ten same-length soybean seeds ( $1 \times 1 \times 5 \mathrm{~mm})$ selected by random sampling from each product group (CF and $\mathrm{OF}$ ) were fixed in 5\% glutaraldehyde (in $0.1 \mathrm{M}$ phosphate buffer, pH 7.4) for 1 week. After being washed with the sample buffer, they were post-fixed with $1 \%$ osmic acid medium in $0.1 \mathrm{M}$ phosphate buffer (pH 7.4). Dehydration using a 50-to-100\% ethanol series was performed before saturation with propylene oxide. After embedding the seeds in epoxy resin (Epon 812: Ohken Co., Tokyo, Japan), ultra-thin sections (90 nm thick) were prepared using an ultra-microtome (MT 6000 Sorvall Instruments: Du Pont Co., Delaware, USA). They were stained with $1 \%$ uranyl acetate and lead citrate and observed under a transmission electron microscope (H-800: Hitachi, Tokyo, Japan) with an accelerating voltage of $100 \mathrm{kV}$.

\section{Statistical analysis}

Means and standard errors of the proximate composition and proximate mineral compositions of each sam- ple were calculated after long-term storage. A $t$-test was used to determine significant differences between the proximate compositions of $\mathrm{CF}$ and OF products after long-term storage.

\section{RESULTS AND DISCUSSION}

Changes in the chemical and histological properties of farming products occur after harvest and during storage. For example, there are changes in smell, color and texture (Narayan et al., 1988a, b; Zhou et al., 2002). These changes are caused by consumption of organic compounds (such as starch, protein, lipids, vitamins, etc.) by respiratory processes and oxidation (Clark and Snyder, 1991; Tanteeratarm et al., 1989; Angulo et al., 1998; Zhou et al., 2002; Rukunudin et al., 2004). Furthermore these chemical changes are effected by the humidity (Patil et al., 1986) and temperature conditions (Kaushik et al., 1987; Sorour and Uchino, 2004) during storage, and they are accompanied by histological changes (especially in texture) (Ojijo et al., 2000a, b; Zhou et al., 2002).

The applied farming system itself affects the chemical and histological properties of the products (Yoshida et al., 1984a, b, c; Benge et al., 2000; Brandt and Mølgaard, 2001). In the present study, we observed changes in the chemical compositions and histological structure of the CF and OF soybean seeds under long-term storage for 9 years under hermetic conditions at room temperature and shielded from light. In the present study, each of the sample products was kept in good condition, and there was no evidence of mold, harmful insect damage, or putrefaction (Fig. 2). There

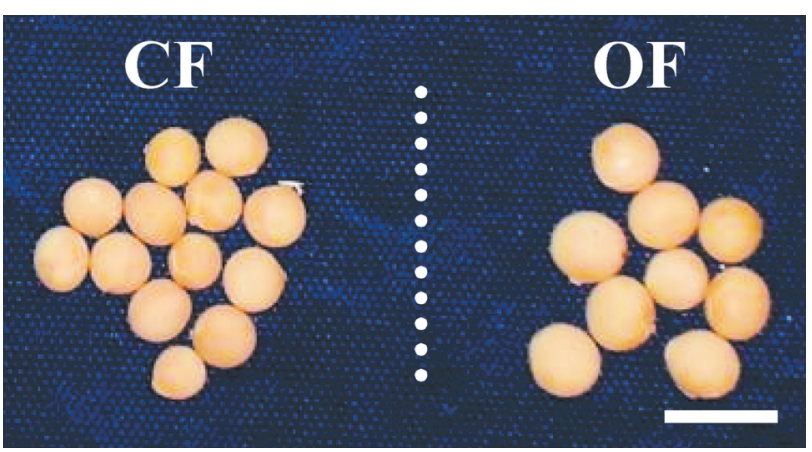

Fig. 2. Photograph of each sample after long-term (9 years) storage. CF: conventional farming, OF: organic farming. Bar $=$ $1 \mathrm{~cm}$.

Table 1. Protein, lipid contents and mineral compositions of the soybean seeds by conventional (CF) and organic (OF) farming systems after harvest

\begin{tabular}{lcc}
\hline & \multicolumn{2}{c}{ Farming system } \\
\cline { 2 - 3 } & CF & OF \\
\hline Protein (\% in dry weight) & 33.1 & 35.1 \\
Lipid & 18.1 & 17.2 \\
Ca (mg $₫ \mathrm{~kg}^{-1}$ in dry weight) & 1890 & 2010 \\
$\mathrm{~K}$ & 17500 & 18100 \\
$\mathrm{P}$ & 4210 & 4510 \\
\hline
\end{tabular}


Table 2. Protein, lipid and ash contents of the soybean seeds by conventional (CF) and organic (OF) farming systems after long-term storage

\begin{tabular}{|c|c|c|c|c|c|}
\hline & \multicolumn{4}{|c|}{ Farming system } & \multirow[b]{3}{*}{$t$-Test } \\
\hline & \multicolumn{2}{|c|}{$\mathrm{CF}$} & \multicolumn{2}{|c|}{$\mathrm{OF}$} & \\
\hline & Mean & S.D. & Mean & S.D. & \\
\hline Dry matter (\%) & 90.5 & 0.36 & 91.0 & 0.31 & $P<0.05$ \\
\hline Protein (\% in dry weight) & 32.9 & 0.64 & 36.2 & 1.20 & $P<0.001$ \\
\hline Lipid & 8.71 & 1.07 & 8.75 & 0.77 & $P>0.05$ \\
\hline Ash & 3.82 & 0.14 & 3.96 & 0.16 & $P>0.05$ \\
\hline
\end{tabular}

S.D.: standard deviation.

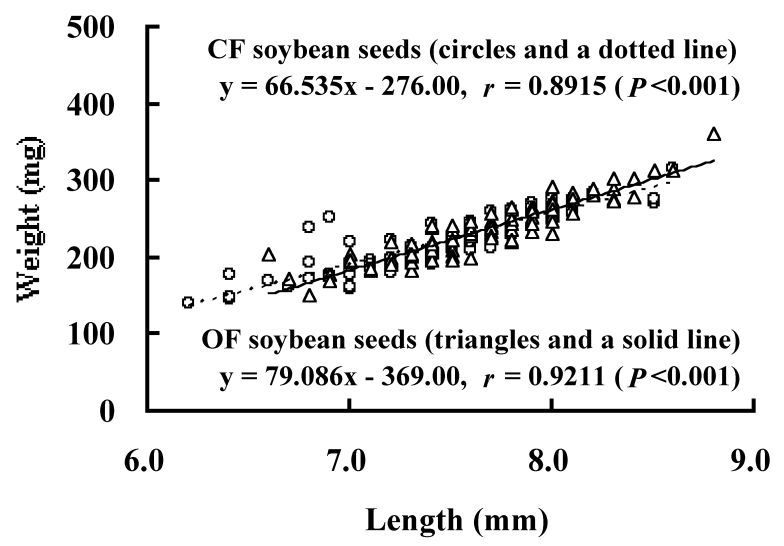

Fig. 3. The correlation of length and weight of soybean seeds after long-term (9 years) storage. $n=100$.
Table 3. Difference of mineral contents of soybeans seeds by conventional (CF) and organic (OF) farming systems after long-term storage.

\begin{tabular}{lcc}
\hline & \multicolumn{2}{c}{ Farming system } \\
\cline { 2 - 3 } & CF & OF \\
\hline $\begin{array}{l}\text { Difference } \\
>+100 \mathrm{mg}^{-1} \mathrm{~kg}^{-1}\end{array}$ & - & $\mathrm{K}(+4250 \mathrm{mg})$ \\
$+50 \sim 100$ & - & $\mathrm{Ca}, \mathrm{P}$ \\
$+10 \sim 50$ & $\mathrm{~S}$ & $\mathrm{Mg}$ \\
$+1 \sim 10$ & $\mathrm{Zn}$ & $\mathrm{B}, \mathrm{Ba}, \mathrm{Ga}, \mathrm{Mn}, \mathrm{Sm}$ \\
\hline
\end{tabular}

Not difference

$\mathrm{Ag}, \mathrm{Al}, \mathrm{As}, \mathrm{Au}, \mathrm{Be}, \mathrm{Bi}, \mathrm{Cd}, \mathrm{Ce}, \mathrm{Co}, \mathrm{Cr}, \mathrm{Cu}, \mathrm{Dy}, \mathrm{Er}, \mathrm{Eu}, \mathrm{Fe}, \mathrm{Gd}$,

Ge, Hf, Hg, Ho, In, Ir, La, Li, Lu, Mo, Nd, Ni, Pb, Pr, Pt, Ph, Ru,

$\mathrm{Sb}, \mathrm{Sc}, \mathrm{Sn}, \mathrm{Sr}, \mathrm{Ta}, \mathrm{Tb}, \mathrm{Te}, \mathrm{Ti}, \mathrm{Tl}, \mathrm{Tm}, \mathrm{V}, \mathrm{W}, \mathrm{Y}, \mathrm{Yb}, \mathrm{Zr}$,

Table 4. Comparison of breaking strength and $\mathrm{pH}$ of soybean seeds by conventional (CF) and organic (OF) farming systems after long-term storage

\begin{tabular}{lcccccc}
\hline & \multicolumn{6}{c}{ Farming system } \\
\cline { 2 - 3 } \cline { 5 - 7 } \cline { 5 - 7 } & Mean & S.D. & & Mean & S.D. & $t$-Test \\
\cline { 2 - 3 } $\begin{array}{l}\text { Breaking strength } \\
(2 \mathrm{kgw})\end{array}$ & 16.7 & 3.5 & & 17.7 & 2.0 & $P<0.05$ \\
$\mathrm{pH}$ & 6.18 & 0.00 & & 6.25 & 0.02 & $P<0.05$ \\
\hline
\end{tabular}

S.D.: standard deviation.

tended to be no differences in protein and lipid content of soybean seeds after harvest (Table 1). In addition, lipid content of soybean seeds of each group decreased about $10 \%$ after long-term storage (Table 1 and 2 ). In the samples after long-term storage, however, the correlation $(r=0.8915)$ between length and weight of $\mathrm{CF}$ soybean seeds was lower than that of OF seeds $(r=$ 0.9211) (Fig. 3), and the dry matter and protein content of the OF soybean seeds were higher $(P<0.05$ and 0.001) than CF seeds (Table 2). On the other hand, there were differences in the mineral compositions (more than $100 \mathrm{mg}$ ) of $\mathrm{Ca}, \mathrm{K}$ and $\mathrm{P}$ content between $\mathrm{CF}$ and OF soybean seeds after harvest (Table 1). However, there was a great difference (more than $4000 \mathrm{mg}$ ) in mineral content, in particular $\mathrm{K}$ content, between $\mathrm{CF}$ and $\mathrm{OF}$ soybean seeds after long-term storage (Table 3).

Next, we observed the morphological cell structure of CF and OF soybean seeds after long-term storage. By scanning electron microscopy, there was no difference in the morphological structure of the surface of the seed coat and surface of seeds which stripped off seed coat between CF and OF soybean seeds (Fig. 4). Cross-sections of soybean seeds were used for optical microscopy (Fig. 1). CF soybean seeds of soybean contained many collapsed areas in parts A-D (Figs. 5a, c, e and g; asterisks), whereas only few such areas were found in OF soybean seeds (Figs. 5b and f; asterisks). Of special note, cotyledon cells of CF soybean seeds were transformed (Fig. 5g). Optical microscopic analysis revealed that there were many collapsed areas and gaps in the external and internal parts of the CF soybean seeds, but not in those of OF seeds (Fig. 5). The storage conditions in this study were thought to be too severe (the samples were kept at ambient temperature). Nevertheless, the OF products nearly maintained their 

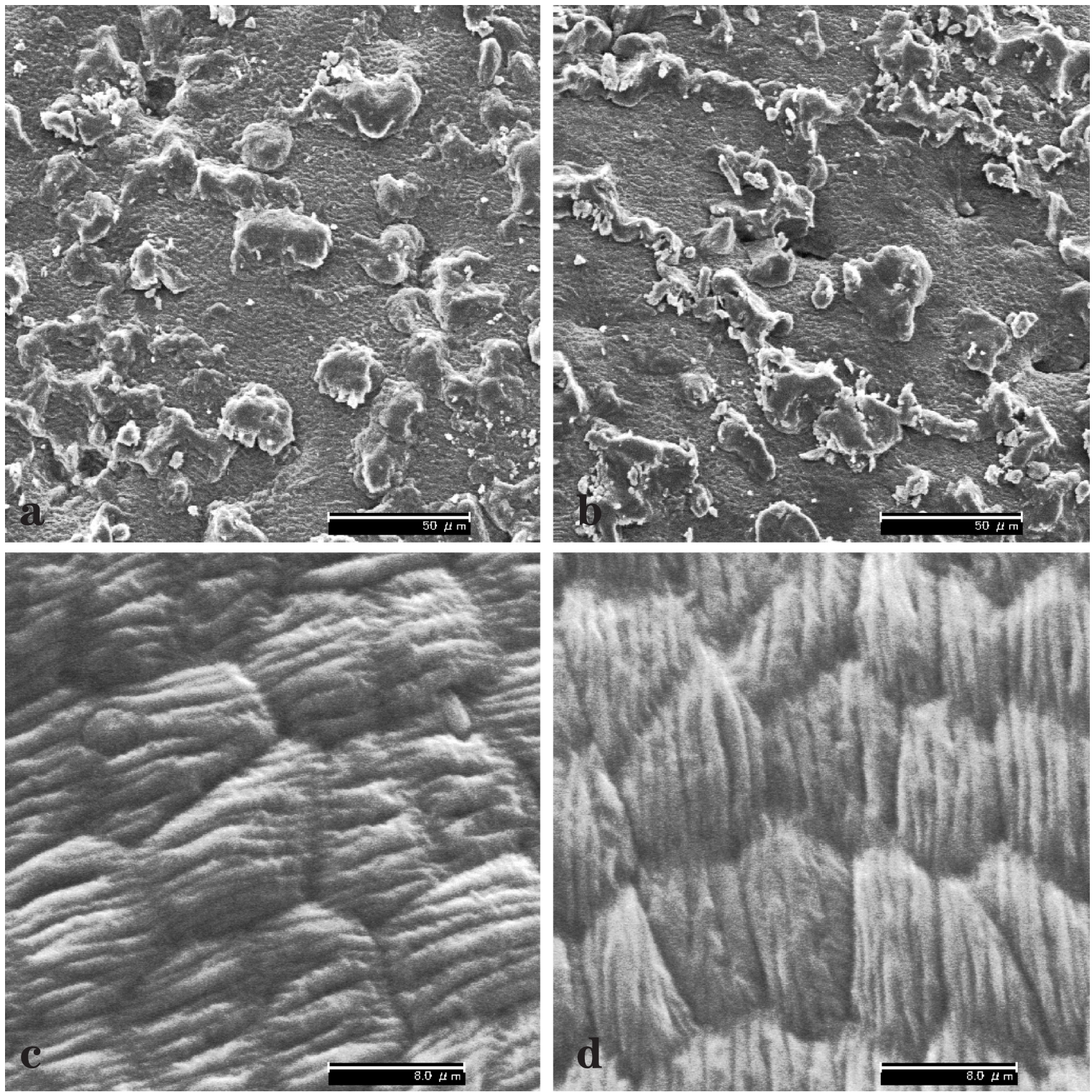

Fig. 4. Scanning electron microscopic photographs of surface of seed coat $(a, b)$ and surface of seeds which stripped off seed coat (c, d) of soybean seeds after long-term (9 years) storage. a, c: CF, b, d: OF. Bar $=50(a, b)$ and $8(c, d) \mu \mathrm{m}$.

original morphology. These results indicate histological differences between $\mathrm{CF}$ and $\mathrm{OF}$ soybean seeds and suggest that CF soybean seeds became porous under storage, resulting in leakage of cell contents. Cross-sections of part $\mathrm{C}$ of soybean seeds were observed by transmission electron microscope (Fig. 1). In seeds of the CF soybean, collapsed cell walls (Figs. 6a, e, 7c, e; asterisks) and protein bodies (Figs. 6c and 7a; black arrows) were observed. The plasma membrane of the CF soybean seeds was broken, and internal organelles were observed flowing out (Fig. 7c; white arrows). No collapsed organelles were detected in the seeds of the OF soybeans (Figs. 6 and 7). Study of the OF soybean seeds revealed clear protein bodies (Figs. 6b and $\mathbf{7 b}$; PB), lipid granules (Fig. 7b; LG) and thick cell walls (Figs. 7d and f; CW). In addition, protein bodies were systematically surrounded by clear lipid granules (Fig. 7b), and internal organelles were completely contained by the thick cell walls (Fig. 7d).
Just after harvest, Ca content of CF soybean seeds was lower (120 mg) than OF ones (Table 1). The Ca which exists in cell wall has functions such as the maintenance of cell wall structure by combination between cell wall components (Tobias et al., 1993; White and Broadley, 2003). In the cell wall of plants, Ca decreases under threshold concentration for maintaining the cell wall structure sometimes, and happen the Ca deficiency, for example cracking of the skin in tomato fruit (White and Broadley, 2003). Plants that have low Ca content show advanced ageing of tissue and increases in bacterial infections. Therefore, low molecular weight contents may escape from tissue which has low Ca content (Fig. 5). In this study, after 9 years of storage, the cell morphological structure (in particular, the cell wall) of CF soybean seeds collapsed (Figs. 7c and e). We believe that the cell wall of CF soybean seeds collapses during long-term storage because of low Ca content. The breaking strength (an index of tissue strength) of 


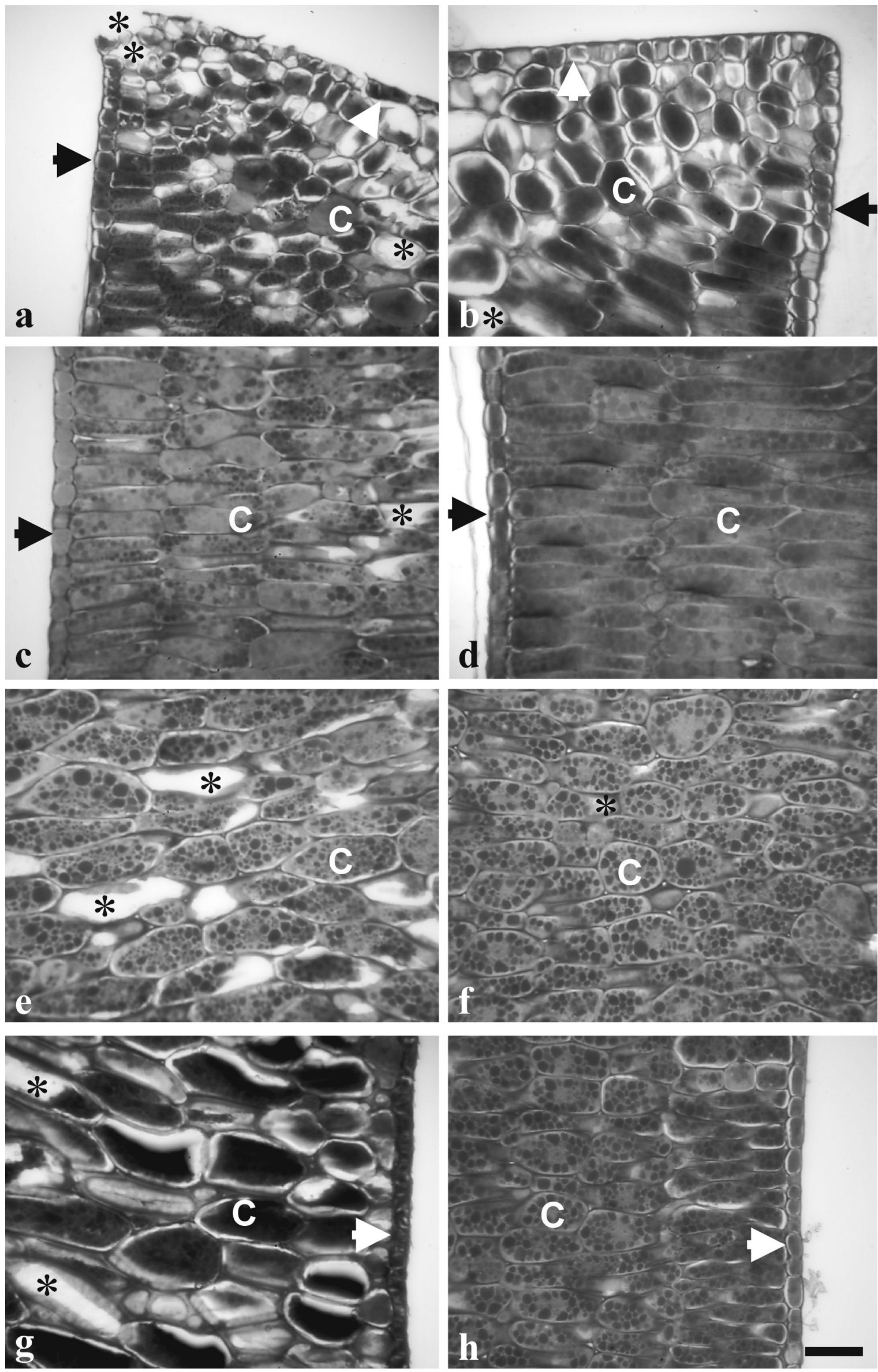

Fig. 5. Optical microscopic photographs of part A (a, b), B (c, d), C (e, f) and D ( g, h) of soybean seeds after long-term (9 years) storage. a, c, e, g: CF, b, d, f, h: OF. C: cotyledon cells. Black arrow: inner layer, White arrow: outer layer. Asterisks mark collapsed areas in soybean seeds. Bar $=50 \mu \mathrm{m}$. 

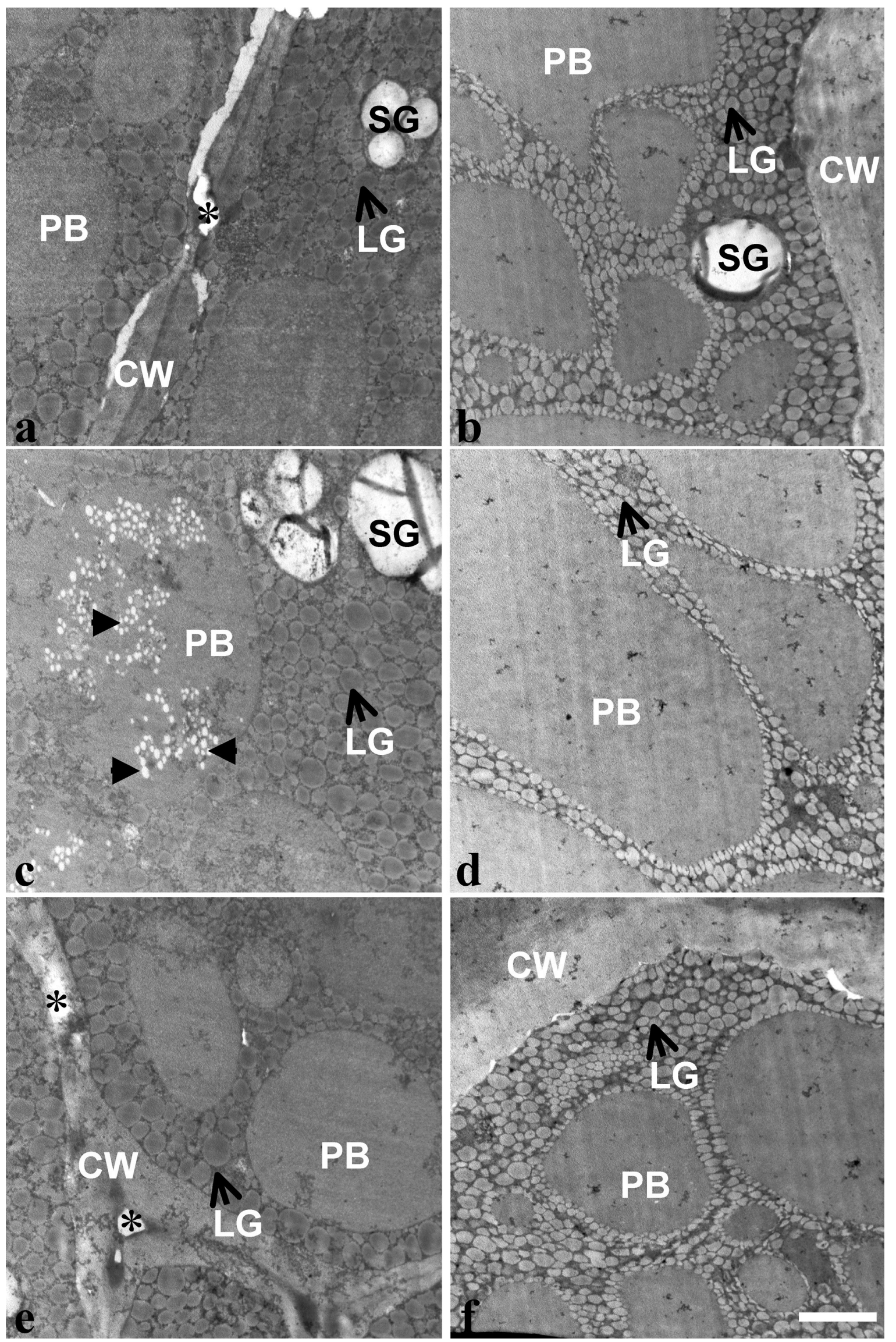

Fig. 6. Transmission electron microscopic (TEM) photographs of part C of soybean seeds after long-term (9 years) storage. a, c, e: CF, b, d, f: OF. CW: cell wall, LG: lipid granule, PB: protein body, SG: starch granule. Asterisks: gaps and collapsed parts, Black arrows: collapsed parts. Bar $=2 \mu \mathrm{m}$. 


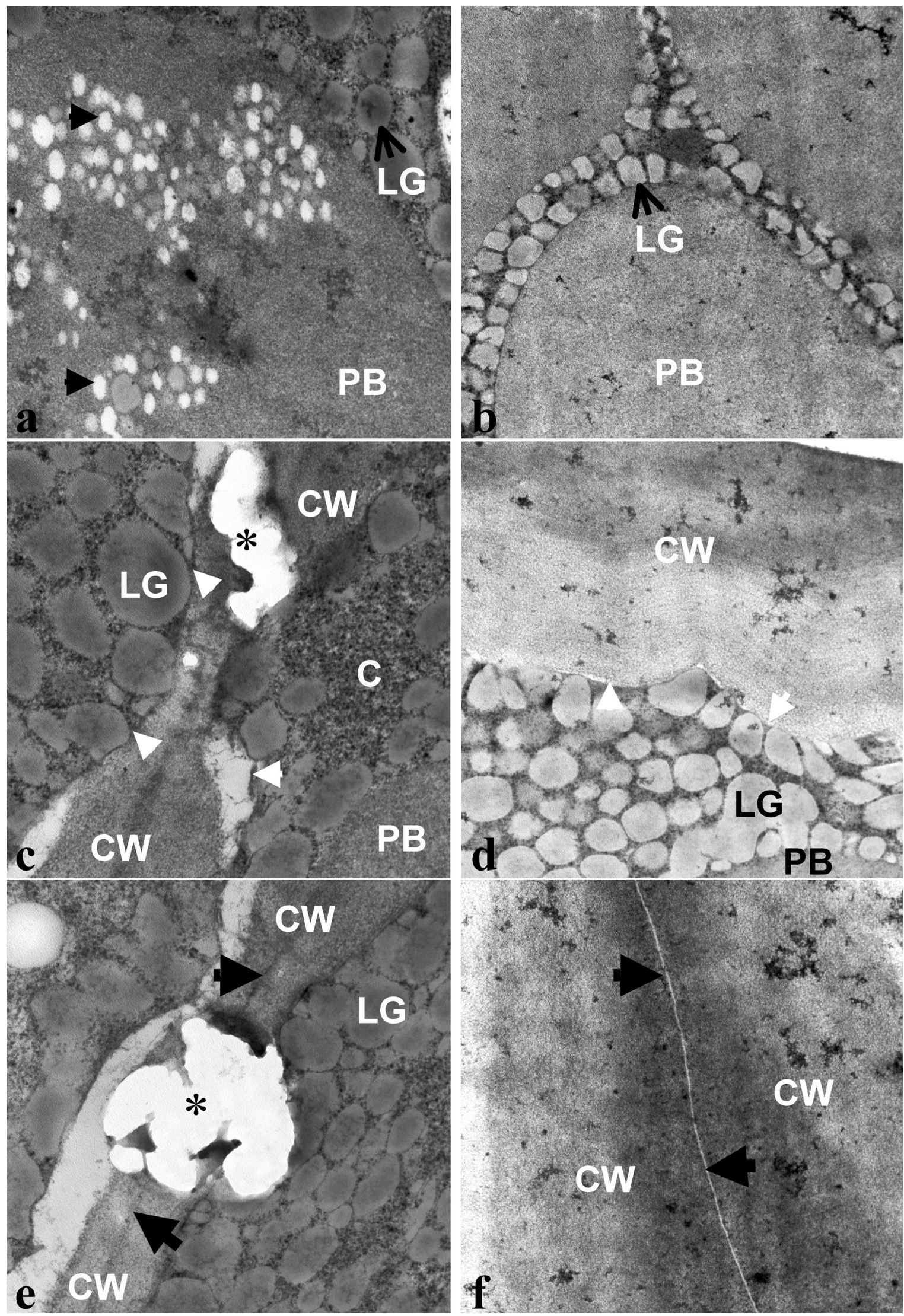

Fig. 7. TEM photographs of part $\mathrm{C}$ of soybean seeds after long-term (9 years) storage. a, c, e: CF, b, d, f: OF. C: cytoplasm, CW: cell wall, LG: lipid granule, PB: protein body. Asterisk: collapsed parts, Black arrows: collapsed parts, Large black arrows: boundary between cell walls, White arrows: plasma membrane. Bar $=500 \mathrm{~nm}$. 
CF soybean seeds after long-term storage was lower than $\mathrm{OF}$ ones (Table 4). In addition, the loss of contents of CF soybean seeds was revealed by optical microscopy (Fig. 5) and a decrease of dry matter and other chemical compositions was observed (Table 2). In this study, there was a great difference in $\mathrm{K}$ contents (OF: + $4250 \mathrm{mg}$ ) between CF and OF soybean seeds after long-term storage in comparison with the data after harvest (Table $\mathbf{1}$ and 3). It is thought that the low $\mathrm{pH}$ of CF soybean seeds after long-term storage may be caused by the loss of $\mathrm{K}$ which exists mostly in the cytoplasm (Table 4). Conceivably, the strong cell walls of $\mathrm{OF}$ soybean seeds help maintain the histological structure of seeds during long-term storage. Generally, the dry weight of farming products decreases (Krishnan et al., 2004), and chemical composition changes during storage (Narayan et al., 1988a, b; Zhou et al., 2002). However, there are no reports like this study, comparing the chemical and histological changes in $\mathrm{CF}$ and $\mathrm{OF}$ products under long-term storage. The results of this study make it clear that CF practices accelerate the deterioration of the cellular morphological properties of its products. After all, the low Ca contents of CF soybean seeds caused fragile cell walls and loss of contents in this study.

We believe that the difference in the chemical and histological characteristics between CF and OF soybean seeds was caused by the type of applied fertilizer, namely chemical or organic. It is known that the properties of soil subjected to inorganic farming differ from soil subjected to organic farming in physiochemical (Clark et al., 1998; Gunapala and Scow, 1998; Liebig and Doran, 1999; Schjønning et al., 2002) and biological points (Nakamura et al., 2000; Fujita and Fujiyama, 2001a, b; Hirano et al., 2001). The OF fields in the present study contained a rich soil fauna which in turn is likely to affect the physicochemical properties of the soil (Nakamura et al., 2003). In the OF soybean field, soil properties [depth: $0 \sim 16 \mathrm{~cm}, \mathrm{pH}: 5.35 \sim 5.66$, electrical conductivity (EC): 30.9 45.5 $\mu \mathrm{S}$, organic carbon (Org-C): $1.8 \sim 4.8 \%$, cation exchange capacity (CEC): 19.1 25.6 meq/100g, and base-saturation: 36.5 59.8\%] differed from those of the CF fields (depth: $0 \sim 22 \mathrm{~cm}$, pH: 5.60, EC: $54.7 \mu \mathrm{S}$, Org-C: 1.6\%, CEC: $22.0 \mathrm{meq} / 100 \mathrm{~g}$, and base-saturation: $36.1 \%)$. Also, the mean of the total number of enchytraeids found in soil samples from the study period (Oct. 1991 to Oct. 1998) in the OF soybean field was 549.9 individuals $/ \mathrm{m}^{2}$ (soil depth: $0 \sim 5 \mathrm{~cm}$ ), in contrast with that of the $\mathrm{CF}$ field, which had 16.7 individuals $/ \mathrm{m}^{2}$ ) (Nakamura et al., 2003). In addition, there were no earthworms in the CF field throughout the study period, but abundant earthworms were observed in the OF field (Nakamura et al., 2003). These results from the present study resemble the tendencies of the soil properties of both field types (CF and OF) in other reports (Schjønning et al., 2002; Lotter, 2003). Thus, both biological and physicochemical factors may affect product quality of the different farming systems (Nakamura, 1988, 1989; Woese et al., 1997; Brandt and Mølgaard, 2001; Nakamura et al.,
2003). We guessed that the difference of change of $\mathrm{CF}$ and OF soybean seeds during long-term storage was caused by initial Ca contents. In another report (Kujira and Nakayama, 1997), there was a difference (OF: + $13 \mathrm{mg} / 100 \mathrm{~g}$, no significance) of Ca contents between CF and $\mathrm{OF}$ green soybean seeds after harvest. Therefore, we consider that the absorption of $\mathrm{Ca}$ is inhibited by antagonism between minerals, in particular $\mathrm{N}, \mathrm{P}, \mathrm{K}$ which is present at higher levels due to chemical fertilizer in CF soybean fields.

\section{ACKNOWLEDGEMENT}

The authors are indebted to Mr. Manabu Fukugauchi and Miss Rie Ogawa of managing stuff in Nara Prefectural Institute of Industrial Technology for valuable assistance with observation by SEM and measurement of simple qualitative analysis of mineral compositions by ICP.

\section{REFERENCES}

Altieri, M. A. and C. I. Nicholls 2003 Soil fertility management and insect pests: harmonizing soil and plant health in agroecosystems. Soil and Tillage Research, 72: 203-211

Angulo, A. J., J. M. Romera, M. Ramírez and A. Gil 1998 Effects of storage conditions on lipid oxidation in infant formulas based on several protein sources. Journal of American Oil Chemists' Society, 75: 1603-1607

Anonymous 1990 Methods of plant nutrition. Committee of editor for methods of plant nutrition. Hakuyuusha, Tokyo (Japan), p. 488

Asami, D. K., Y.-J. Hong, D. M. Barrett and A. E. Mitchell 2003 Comparison of the total phenolic and ascorbic acid content of freeze-dried and air-dried marionberry, strawberry, and corn grown using conventional, organic, and sustainable agricultural practices. Journal of Agricultural and Food Chemistry, 51: 1237-1241

Benge, J. R., N. H. Banks, R. Tillman and H. Nihal De Silva 2000 Pairwise comparison of the storage potential of kiwifruit from organic and conventional production systems. New Zealand Journal of Crop and Horticultural Science, 28: 147-152

Brandt, K. and J. P. Mølgaard 2001 Organic agriculture: does it enhance or reduce the nutritional value of plant foods?. Journal of the Science of Food and Agriculture, 81: 924-931

Calderwood, D. L., R. R. Cogburn, B. D. Webb and M. A. Marchetti 198 Aeration of rough rice in long-term storage. Transactions of the American Society of Agricultural Engineers, 27: 1579-1585

Clark, M. S., W. R. Horwath, C. Shennan and K. M. Scow 1998 Changes in soil chemical properties resulting from organic and low-input farming practices. Agronomy Journal, 90: 662-671

Clark, P. K. and H. E. Snyder 1991 Hydroperoxide formation in soybean seeds during storage. Journal of American Oil Chemists' Society, 68: 346-347

Folch, J., M. Lees and G. H. S. Stanly 1957 A simple method for the isolation and purification of total lipides from animal tissues. Journal of Biological Chemistry, 226: 497-509

France, R. 1921 Das Edaphon. Untersuchungen Zur Okologie der bodenlewohnenden Mikroorganismen. Stuttgartm (Germany), p. 99

Fujita, M. and S. Fujiyama 2001a Comparison of soil fauna (Oribatids and Enchytraeids) between conventional and organic (tillage and no-tillage practices) farming crop fields in Japan. Pedosphere, 11: 11-20

Fujita, M. and S. Fujiyama 2001b How can the minor species, 
Tectocepheus minor (Oribatida), dominate T. velatus in a no-tillage crop field? Pedobiologia, 45: 36-45

Gunapala, N. and K. M. Scow 1998 Dynamics of soil microbial biomass and activity in conventional and organic farming systems. Soil Biology and Biochemistry, 30: 805-816

Hirano, K., M. Hayatsu, I. Nioh and H. Nakai 2001 Comparison of nitrogen-fixing bacterial flora of rice rhizosphere in the fields treated long-term with agrochemicals and non-agrochemicals. Microbes and Environments, 16: 155-160

Hoshi, Y., F. Yamauchi and K. Shibasaki 1982 On the role of disulfide bonds in polymerization of soybean $7 \mathrm{~S}$ globulin during storage. Agricultural and Biological Chemistry, 46: 2803-2807

Hou, D. H. and SK.-C. Chang 2004a Structural characteristics of purified glycinin from soybeans stored under various conditions. Journal of Agricultural and Food Chemistry, 52: $3792-3800$

Hou, H. J. and K. C. Chang 2004b Structural characteristics of purified $\beta$-conglycinin from soybeans stored under four conditions. Journal of Agricultural and Food Chemistry, 52: 7931-7937

Kaushik, S. K., G. S. Chauhan and G. S. Bains 1987 Changes in physico-chemical properties of defatted soy flour during storage. Journal of Food Science and Technology, 24: 159-163

Krishnan, P., S. Nagarajan and A. V. Moharir 2004 Thermodynamic characterisation of seed deterioration during storage under accelerated ageing conditions. Biosystems Engineering, 89: 425-433

Kujira, Y. and M. Nakayama 1997 Effects of organic fertilizer on ascorbic acid content and quality of vegetables. Hokuriku Crop Science, 32: 91-94

Liebig, M. A. and J. W. Doran 1999 Impact of organic production practices on soil quality indicators. Journal of Environmental Quality, 28: 1601-1609

Lotter, D. W. 2003 Organic Agriculture. Journal of Sustainable Agriculture, 21: 59-128

Matsue, Y., Y. Uchimura, H. Sato and T. Ogata 2003 An efficient method for evaluating the palatability deterioration during storage in rice. Plant Production Science, 6: 107-111

Nakamura, Y. 1988 The effect of soil management on the soil faunal makeup of a cropped andosol in central Japan. Soil and Tillage Research, 12: 177-186

Nakamura, Y. 1989 Oribatids and enchytraeids in ecofarmed and conventionally farmed dryland grainfields of central Japan. Pedobiologia, 33: 389-398

Nakamura, Y., T. Fujikawa and M. Fujita 2000 Long-term changes in the soil properties and the soil macrofauna and mesofauna of an agricultural field in northern Japan during transition from chemical-intensive farming to nature farming. Journal of Crop Production, 3: 63-75

Nakamura, Y., H. Shiraishi and M. Nakai 2003 Earthworm and enchytraeid numbers in soybean-barley fields under till and no-till cropping systems in Japan during nine years. Memoirs of the Faculty of Agriculture, Ehime University, 48: 19-29

Narayan, R., G. S. Chauhan and N. S. Verma 1988a Changes in the quality of soybean during storage. Part 1-Effect of storage on some physico-chemical properties of soybean. Food Chemistry, 27: 13-23

Narayan, R., G. S. Chauhan and N. S. Verma 1988b Changes in the quality of soybean during storage. Part 2-Effect of soybean storage on the sensory qualities of the products made therefrom. Food Chemistry, 30: 181-190

Neera, P., M. Katano and T. Hasegawa 1992 Rice culture under nature farming in Japan. Proceedings of Faculty of Agriculture, Kyushu Tokai University, 11: 67-74

Neera, P., M. Katano and T. Hasegawa 1999 Comparison of rice yield after various years of cultivation by natural farming. Plant Production Science, 2: 58-64

Ojijo, O. N. K., T. Kimura, N. Shimizu and H. Koaze 2000a Characterization of textural and chemical changes in soybean cotyledons subjected to accelerated storage and salt soaking.
Journal of the Society of Agricultural Structures, Japan, 30: $353-364$

Ojijo, O. N. K., T. Kimura, N. Shimizu and H. Koaze 2000b Viscoelastic components of hard-to-cook defect in soybean cotyledons subjected to accelerated storage. Journal of the Society of Agricultural Structures, Japan, 30: 383-394

Okada, M. 1982 True Health. Church of World Messianity, Atami (Japan), p.184

Patil, K. B., S. C. Shivamurthy and R. C. Badami 1986 Effect of fungi on the lipid composition of soybean during storage at different levels of humidity. Fette Seifen Anstrichmittel, $\mathbf{8 8}$ $18-19$

Reganold, J. P., J. D. Glover, P. K. Andrews and H. R. Hinman 2001 Sustainability of three apple production systems. Nature, 410: 926-930

Rukunudin, I. H., C. J. Bern, M. K. Misra and T. B. Bailey 2004 Carbon dioxide evolution from fresh and preserved soybeans. Transactions of the American Society of Agricultural Engineers, 47: 827-833

Schjønning, P., S. Elmholt, L.J. Munkholm and K. Debosz 2002 Soil quality aspects of humid sandy loams as influenced by organic and conventional long-term management. Agriculture Ecosystems and Environment, 88: 195-214

Sorour, H. and T. Uchino 2004 Effect of changing temperature on the deterioration of soya beans. Biosystems Engineering, 87: $453-462$

Sripichitt, A., E. Nawata and S. Shigenaga 1989 Deterioration of stored soybean seeds in simulated humid tropical conditions. Japanese Journal of Tropical Agriculture, 33: 18-24

Standard tables of food composition in Japan (STFCJ). 2001. Resources Council, Science and Technology Agency, Tokyo (Japan), p. 14

Tanteeratarm, K., L. S. Wei and M. P. Steinberg 1989 Effect of soybean maturity on storage stability and process quality. Journal of Food Science, 54: 593-597

Tilman, D., K. G. Cassman, P. A. Matson, R. Naylor and S. Polasky 2002 Agricultural sustainability and intensive production practices. Nature, 418: $671-677$

Tobias, R. B., W. S. Conway, C. E. Sams, K. C. Gross and B. D. Whitaker 1993 Cell wall composition of calcium-treated apples inoculated with Botrytis cinerea. Phytochemistry, 32: 35-39

White, P. J. and M. R. Broadley 2003 Calcium in plants. Annals of Botany, 92: 487-511

Wilkins, C. K. and S. Scholl 1989 Volatile metabolites of some barley storage molds. International Journal of Food Microbiology, 8: 11-17

Woese, K., D. Lange, C. Boess and K. W. Bögl 1997 A comparison of organically and conventionally grown foods-Results of a review of the relevant literature. Journal of the Science of Food and Agriculture, 74: 281-293

Yamamoto, A. and K. Shirakawa 1999 Annealing of long-term stored rice grains improves gelatinization properties. Cereal Chemistry, 76: 646-649

Yoshida, K., S. Mori, K. Hasegawa, N. Nishizawa and K. Kumazawa 1984a Taste of tomato fruits cultured with organic fertilizers in comparison with inorganic fertilizers. Journal of Japanese Society of Nutrition and Food Science, 37: 115-121

Yoshida, K., S. Mori, K. Hasegawa, N. Nishizawa and K. Kumazawa 1984b Reducing sugar, organic acids and vitamin C contents of tomato fruits cultured with organic fertilizers in comparison with inorganic fertilizers. Journal of Japanese Society of Nutrition and Food Science, 37: 123-127

Yoshida, K., S. Mori, K. Hasegawa, N. Nishizawa and K. Kumazawa $1984 \mathrm{c}$ Texture of tomato fruits cultured with organic fertilizers in comparison with inorganic fertilizers. Journal of Japanese Society of Nutrition and Food Science, 37: 267-272

Zhou, Z., K. Robards, S. Helliwell, C. Blanchard 2002 Ageing of stored rice: changes in chemical and physical attributes. Joumal of Cereal Science, 35: 65-78 